\title{
From Windows to Mirrors: My Reading Journey
}

\author{
Nimrit Basra, Simon Fraser University
}

As a child, I used to look to books as an opportunity for adventure. I was able to jump into different worlds and be part of stories that I found more exciting and interesting than my own life. After I had picked up a book, I would be immersed in it until I finished. When I was in elementary school, I borrowed a copy of The $W$ izard of $\mathrm{O} z$ from the local public library. Unable to put it down, I took it into the bathtub with me, eager to learn where the Yellow Brick Road led. While trying to flip a page, the book slipped from my fingers. I heard a dreadful *splash* and scrambled to pull the book out of the water... but it was too late. I hid that soggy book under my bed where it stayed for months, leading me to constantly carry the fear of having my library card revoked.

Looking back, I'm grateful that my mom encouraged reading and ensured books were a large part of my childhood. She always reminded me it was a privilege to borrow books, so you can only imagine the shocked look on her face when we eventually got a statement of fines in the mail for my overdue book. When she made me pull that book from under my bed and took me to the library to own up to my mistake, I was - to my surprise - relieved. I was glad that thinking about the library filled me with a sense of joy once again. And carrying that guilt would have been a heavy burden to bear, especially because we were regulars at our public library. I remember my mom signing my siblings and me up for the Surrey Public Library Book Club every summer break from pre-school to grade six, just to make sure we kept reading even though we were not in school. And, when we were in school, I remember her being in charge of the Scholastic Book Fairs, where she would spend countless hours setting up, taking down, and sharing her love of reading with my classmates and me.

As a result, in elementary school I used to read books from all genres, but my favourites always included magic. I vividly remember sitting in the treehouse that my dad had built in the backyard and reading the Magic Treehouse books by

ENGL487W - Summer 2021 
Mary Pope Osborne. I had a lot of questions about the world and used to be curious about the universe outside of my community, so these books satisfied my craving to explore. Living vicariously through the characters allowed me to feel as though their adventures were mine as well. I still remember the day I finished the last book of the Magic Treebouse series. I didn't know what to read next. But in grade four, I fell for Harry Potter... and I fell hard. I was utterly obsessed, and even though I read other book series such as The Lord of the Rings, Narnia, and Percy Jackson, nothing could compare in my mind. From my school supplies to my clothes to the posters on my wall - everything had to be Harry Potter-themed. While dressing up as a wizard and pretending sticks had magical powers did make me a bit of a social outcast, I was happy. In hindsight, even though this happiness stemmed from a place of unawareness and naïveté, it reflects a version of myself who was not troubled by the disappointments of the real world.

I often reminisce about lying in my mom's bed as a child and having her read to my siblings and me every night. Because there is a relatively large age gap between me and my siblings, we would argue about which books to read, eventually deciding between Harry Potter and a picture book of my little siblings' choice - most likely The Very Hungry Caterpillar. But looking back, I don't remember us bickering and getting upset if Mom did not choose our book. What I remember is us spending time together. I stopped reading with my mom when I was twelve years old, and I regret this. I remember entering high school and thinking I was too cool to spend time with my mom. I recall my little sister and brother wanting to read together, but I ignored them because I thought I was too old for that. If I had a magic treehouse or a magic wand and I could go back in time and change something, it would be this.

But growing up is inevitable. I was starting to see the world differently and becoming aware of issues affecting others as well as myself. The girl who could blissfully read in her treehouse until it got dark at night and would risk it all by taking a library book into the bathtub began to struggle with finding her identity. Regardless of the genre, popular culture books consistently failed to include characters that allowed me - a second-generation South Asian teenage girl - to see myself as part of the narrative and explore my identity through fiction. I found myself constantly having to make adjustments to relate to characters; looking back, I recognize that I struggled to immerse myself in books because the characters almost always existed outside of a realistic scope for me.

ENGL487W - Summer 2021 
As a result, my reading slowed down. To be honest, I mostly read what was popular so that I could fit in. I had spent much of my elementary school years being an outcast because of the books I was interested in; despite being okay with it when I was younger, I was adamant that I would not be an outsider in high school as well. I read a lot of (un)realistic books about white teenagers doing drugs, having sex, falling in love, and then killing themselves. In this sense, the books served as windows into worlds I would never be part of, as opposed to mirrors that allowed me to be represented, which is what I was looking for. In hindsight, this was an unfulfilling experience, as I had no desire to embody other characters. Instead, I wished these characters would have represented me.

That being said, there are a few books that resonated with me through my teenage years, and I still hold the memories associated with them very close to my heart. When I look at my bookshelf, I see a copy of Stephen Chbosky's The Perks of Being a $W$ allflower and it reminds me of my eighth-grade self who viewed love and friendship as simple and guaranteed. In the far corner rests a copy of S.E. Hinton's The Outsiders - the last book I ever read with my mom. I still have my collection of John Green books because I can't bring myself to get rid of them after how much I begged my parents to pay for the hardcover copies. But I think the hardest one for me is my box set of Harry Potter books buried under a pile of laundry in the far corner of my bedroom. One day in the near future I'll donate them to someone else who may need to escape to Hogwarts... at least that way I prevent any more money from going into J.K. Rowling's pocket.

In between those books I cannot seem to let go of, I also see a transition taking place. I see books written by BIPOC authors that represent me and my beliefs. My collection of books written by activists is growing, and along with every single one of these books comes knowledge that helps propel me to becoming the person I want to be. From Kimberlé Crenshaw writing about intersectionality and racial justice to Alka Joshi sharing the journey of a South Asian woman navigating a classist patriarchal society, there are many authors and literary works that represent my passions and show me how to make the world a better place for everyone - they provide me with the mirrors I've been long searching for. And even though these are books I was not necessarily ready to read when I was in high school, I'm ready to read them now, and for that I am grateful. As an English major in university, I often experience a sense of imposter syndrome. When I hear about all the books my peers read while going through high school and their stories about developing a love for this language, I feel as 
though I am not as well read. I have always believed that English class is more than just Shakespeare and I have not read many of the "classics." Additionally, as somebody whose homeland was once colonized and subjected to harm by the English language, I face internal tension and guilt when I think about pursuing studies in English. However, as I learned through The Wizard of $\mathrm{O}_{2}$ library book fiasco, facing my guilt head-on saves me a lot of heartache in the long run. So, letting these books serve as mirrors alleviates some of this tension and reassures me that there is a reason I am here.

One year ago, my baby cousin came into the world. Being the English major I am, I decided I wanted to get her some books. As I was searching for books to get her, I was happy to see that there were picture books that had little brown girls who looked like us in them. Growing up, I never had the opportunity to see myself in the books I was reading. It gave me hope that as she grows older, she won't have to settle for books that act as windows instead of mirrors and feel as though the world left her behind too. And if they don't exist, maybe I'll just have to write them for her.

(C) Nimrit Basra, 2021 